\title{
Catalysts for Nitrogen Oxides Removal from Flue Gases
}

\author{
Shikina Nadezhda \\ Boreskov Institute of Catalysis \\ Novosibirsk, Russia
}

\author{
Tailakov Oleg \\ T. F. Gorbachev Kuzbass State \\ Technical University \\ Institute of Coal Federal Research \\ Centre Coal and Coal Chemistry \\ SB RAS, \\ Kemerovo, Russia
}

\author{
Ismagilov Zinfer \\ Boreskov Institute of Catalysis \\ Novosibirsk, Russia \\ T. F. Gorbachev Kuzbass State \\ Technical University \\ Institute of Coal Chemistry and \\ Materials Science Federal Research \\ Centre Coal and Coal Chemistry \\ SB RAS \\ Kemerovo, Russia
}

\begin{abstract}
Main catalytic systems for nitrogen oxides removal from flue gases of thermal power plants by the method of selective catalytic reduction (SCR) with ammonia are reviewed. Mechanisms of the process and catalysts preparation methods are examined; analysis of commercial catalytic systems is performed. Novel advanced catalysts with improved functional properties and higher resistance to water vapor and SO2 are examined.
\end{abstract}

Keywords - nitrogen oxides, sulfur dioxide, selective catalytic reduction, catalysts

\section{INTRODUCTION}

Heat power production is one of the main sources of anthropogenic emissions of noxious substances into atmosphere: nitrogen oxides $\left(\mathrm{NO}_{\mathrm{x}}\right)$, sulfur oxides $\left(\mathrm{SO}_{\mathrm{x}}\right)$, particular matter and mercury [1] [2] [3]. Nitrogen oxides give large contribution into formation of photochemical smog, acid rains, depletion of the ozone layer, green house effect; therefore their abatement is a very urgent problem of heat power engineering.

The methods of flue gas treatment for $\mathrm{NO}_{\mathrm{x}}$ removal are commonly divided into wet and dry processes. Wet processes based on the contact of gas with an absorber solution has an advantage of simultaneous $\mathrm{NO}_{\mathrm{x}}$ and $\mathrm{SO}_{\mathrm{x}}$ removal, and this method is used for processes with relatively low $\mathrm{NO}_{\mathrm{x}}$ emissions [4][5]. As NO is only poorly absorbed by aqueous solutions, a stage of its oxidation to nitrogen dioxide is required. In addition, a problem of utilization of $\mathrm{N}_{2} \mathrm{O}_{3}$ and $\mathrm{N}_{2} \mathrm{O}_{4}$ generated as side products requires creation of additional stages of gas treatment.

Dry methods include selective non-catalytic reduction (SNCR) - when nitrogen oxides are reduced selectively by adding a stream of ammonia or urea solution to flue gases at rather high temperatures $\left(850-1050^{\circ} \mathrm{C}\right)$ without a catalyst [6] and selective catalytic reduction (SCR) when nitrogen oxides are reduced selectively to nitrogen and water at relatively low temperatures on the catalysts surface. Using SNCR, reduction levels of $50 \%$ can be achieved and the process requires low capital investment. However in the SNCR process ammonium salts are formed that cause plugging and corrosion of equipment and flue gas duct elements.

Catalytic processes are considered most efficient for pollutants abatement to maximum permissible concentrations both from technological and economical viewpoints [7][8][9].The SCR processes are best techniques for removal of nitrogen oxides. The main products of the processes are harmless nitrogen and water vapor. The SCR processes are carried out using $\mathrm{CO}, \mathrm{H}_{2}$, ammonia or hydrocarbons as reducing agents. The most wide-spread process to remove nitrogen oxides from flue gases is SCR with ammonia. The advantages of this method are relatively low costs and high efficiency. The conversion degree of NO can attain 95\%. This method is used for treatment of emissions from stationary sources, such as enterprises of power generation cycle.

Due to certain conditions of the SCR - short contact times, presence of catalyst poisons in gas stream, narrow temperature window, SCR catalysts must meet a number of requirements: high activity and selectivity, resistance to catalyst poisons, high mechanical strength and high heat conductivity. Catalysts should not be hazardous and their production should not add to the contamination of the environment.

The purpose of this literature review is description of the existing types of $\mathrm{NH}_{3}$-SCR catalysts, review of their preparation methods and analysis of main factors affecting their efficiency.

\section{II. $\mathrm{NH}_{3}$-SCR CATALYSTS. MECHANISM OF THE PROCESS OF SELECTIVE REDUCTION OF NITROGEN OXIDES BY AMMONIA}

At present the method of selective catalytic reduction of nitrogen oxides by ammonia, urea and other ammonia derivatives is considered as one of the best processes used at enterprises of heat power generation. The main advantage of $\mathrm{NH}_{3}$-SCR is less (approximately by 2 orders of magnitude) consumption of a gaseous reductant (as compared to other 
reducing agents), which makes this process rather economic. When ammonia gas (or aqueous ammonia) is used the following reactions occur:

(1)

$$
4 \mathrm{NO}+4 \mathrm{NH}_{3}+\mathrm{O}_{2} \rightarrow 4 \mathrm{~N}_{2}+6 \mathrm{H}_{2} \mathrm{O} \quad \Delta \mathrm{G}_{298}^{\mathrm{o}}=-1627 \mathrm{~kJ} / \mathrm{mol}
$$

$$
2 \mathrm{NO}_{2}+4 \mathrm{NH}_{3}+\mathrm{O}_{2} \rightarrow 3 \mathrm{~N}_{2}+6 \mathrm{H}_{2} \mathrm{O}
$$

$6 \mathrm{NO}+4 \mathrm{NH}_{3} \rightarrow 5 \mathrm{~N}_{2}+6 \mathrm{H}_{2} \mathrm{O}$ (3)

$6 \mathrm{NO}_{2}+8 \mathrm{NH}_{3} \rightarrow 7 \mathrm{~N}_{2}+12 \mathrm{H}_{2} \mathrm{O}(4)$

When urea is used, the reduction proceeds in accordance with the reactions:

$4 \mathrm{NO}+2\left(\mathrm{NH}_{2}\right)_{2} \mathrm{CO}+2 \mathrm{H}_{2} \mathrm{O}+\mathrm{O}_{2} \rightarrow 4 \mathrm{~N}_{2}+6 \mathrm{H}_{2} \mathrm{O}+2 \mathrm{CO}_{2}$

$6 \mathrm{NO}_{2}+4\left(\mathrm{NH}_{2}\right)_{2} \mathrm{CO}+4 \mathrm{H}_{2} \mathrm{O} \rightarrow 7 \mathrm{~N}_{2}+12 \mathrm{H}_{2} \mathrm{O}+4 \mathrm{CO}_{2}(6)$

Urea is a more expensive reagent in comparison with ammonia, but its storage and transportation is safer. It is used mostly at small power plants.

Nitrogen and water vapor are target products, a side product is $\mathrm{N}_{2} \mathrm{O}$. Ammonia used as a reductant undergoes undesirable interaction with oxygen forming nitrogen and nitrogen oxides according to the following reactions:

$$
\begin{aligned}
& 3 \mathrm{NH}_{3}+3 \mathrm{O}_{2} \rightarrow 2 \mathrm{~N}_{2}+6 \mathrm{H}_{2} \mathrm{O}(7) \\
& 4 \mathrm{NH}_{3}+4 \mathrm{O}_{2} \rightarrow 2 \mathrm{~N}_{2} \mathrm{O}+6 \mathrm{H}_{2} \mathrm{O}(8) \\
& 4 \mathrm{NH}_{3}+5 \mathrm{O}_{2} \rightarrow 4 \mathrm{NO}+6 \mathrm{H}_{2} \mathrm{O}(9) \\
& 4 \mathrm{NH}_{3}+7 \mathrm{O}_{2} \rightarrow 4 \mathrm{NO}_{2}+6 \mathrm{H}_{2} \mathrm{O}(10)
\end{aligned}
$$

Usually the reactions of ammonia oxidation accelerate with a temperature increase and compete with the reduction reaction.

\section{A. Mechanisms}

An important factor affecting $\mathrm{NH}_{3}$-SCR process is acidbase catalyst properties that determine peculiar features of the interaction of reagents with the catalysts active surface, the nature and reactivity of the adsorbed species and consequently the activity and selectivity of the catalyst. Ammonia adsorbs differently on Lewis and Brønsted acid centers, and the ammonia adsorption is actually the initial stage of the SCR reaction. The deNOx reaction on oxide catalysts can occur through Eley-Rideal mechanism when the ammonia adsorbed on Lewis centers reacts with gas phase $\mathrm{NO}$ and $\mathrm{NO}_{2}$ producing $\mathrm{N}_{2}$ and $\mathrm{H}_{2} \mathrm{O}$. Marban et al. [10] proposed an EleyRideal mechanism over carbon supported $\mathrm{Mn}_{3} \mathrm{O}_{4}$ catalyst.

Majority of researchers suggest two-center mechanism of nitrogen oxides removal, according to which intermediates like $\mathrm{NH}_{2}$ on Lewis centers [11] or adsorbed ammonia on Brønsted sites [10,12] interact both with gaseous oxygen oxides via Eley-Rideal mechanism and also with adsorbed nitrite intermediate via Langmuir-Hinshelwood mechanism. Meanwhile, $\mathrm{NH}_{4}{ }^{+}$cations adsorbed on Brønsted acid centers do not take place in the SCR reaction. On the contrary, for the $\mathrm{NH}_{3}$-SCR reaction on zeolites of $\mathrm{H}$-type it is suggested that adsorbed $\mathrm{NH}_{3}$ is the most reactive agent when it is bonded to the Brønsted acid sites in zeolites through three hydrogen bonds [13], [14].

Catalysts for the $\mathrm{NH}_{3}$-SCR process can be bulk, consisting from $100 \%$ active component, or supported on different type of supports (oxide, carbon, zeolite).

\section{B. Bulk catalyst}

Bulk oxide catalysts can be divided into single component and mixed oxide catalysts. Among single component catalysts $\left(\mathrm{LaO}_{\mathrm{x}}, \mathrm{CeO}_{\mathrm{x}}, \mathrm{CoO}_{\mathrm{x}}, \mathrm{MnO}_{\mathrm{x}}\right)$ studied in the DeNOx reaction with $\mathrm{NH}_{3}$ [15] manganese oxides are most efficient. The factors determining the activity and selectivity of a $\mathrm{MnO}_{\mathrm{x}}$ based catalyst are manganese oxidation state, oxide crystallinity and specific surface area. It was shown that the catalytic activity of manganese oxides per unit surface area increased in the order: $\mathrm{MnO}<\mathrm{Mn}_{3} \mathrm{O}_{4}<\mathrm{Mn}_{2} \mathrm{O}_{3}<\mathrm{Mn}_{5} \mathrm{O}_{8}<\mathrm{MnO}_{2}$ with an increase of $\mathrm{Mn}$ oxidation state [16]. At the same time the best selectivity is exhibited by $\mathrm{Mn}_{2} \mathrm{O}_{3}$. As was noted by the authors, the $\mathrm{N}_{2}$ selectivity decreases with an increase of manganese oxidation state and elevation of the reaction temperature. These conditions are most favorable for $\mathrm{NH}_{3}$ oxidation and interaction of $\mathrm{NO}$ with $\mathrm{NH}_{3}$ with formation of $\mathrm{N}_{2} \mathrm{O}$. Low selectivity of $\mathrm{MnO}_{2}$ in the SCR is explained by the presence of high concentration of active oxygen species on the catalyst surface, which leads to the fast detachment on hydrogen atoms from $\mathrm{NH}_{3}$ molecule resulting in higher $\mathrm{N}_{2} \mathrm{O}$ selectivity. The same conclusion was drawn by Chinese scientists in [17] devoted to the study of $\mathrm{N}_{2} \mathrm{O}$ formation in the SCR reaction on $\beta-\mathrm{MnO}_{2}$ and $\alpha-\mathrm{Mn}_{2} \mathrm{O}_{3}$. M.Kang and coauthors [18] synthesized and studied manganese oxide catalysts and showed the dependence of their activity on the preparation conditions, chemical nature of the precipitating agent and calcination temperature. The most active $\mathrm{MnO}_{\mathrm{x}}$ catalyst was prepared by a precipitation method using sodium carbonate and calcined at moderate temperatures such as 523 $\mathrm{K}$ and $623 \mathrm{~K}$. This amorphous oxide had the high surface area, the abundant $\mathrm{Mn}^{4+}$ species and the rich concentration of surface oxygen on the surface. In addition, the residual carbonate species on this catalyst also helped $\mathrm{NH}_{3}$ adsorb on the surface, which resulted in the high catalytic activity at low temperatures.

Mixed oxide catalysts are of special interest because of modification of one element by another that takes place due to electron and structural effects. For example, solid solutions of binary metal oxides can be formed between $\mathrm{Mn}, \mathrm{Cu}, \mathrm{Ce}$, etc. [19] [20]. In mixed metal oxides containing manganese, molar ratio between $\mathrm{Mn}$ and a modifying metal influences structural properties and dispersion of manganese oxides.

Casapu et al. [21] studied the effects of different dopants ( $\mathrm{Sn}$, $\mathrm{Nb}, \mathrm{Fe}, \mathrm{Zr}, \mathrm{W}, \mathrm{Pr}$ ) on the low-temperature activity of $\mathrm{MnO}_{\mathrm{x}}-$ $\mathrm{CeO}_{2}$ catalysts for the $\mathrm{NH}_{3}-\mathrm{SCR}$ and showed possibility of the improvement of catalytic characteristics of such catalysts (NO conversion, selectivity, resistance to the presence of $\mathrm{H}_{2} \mathrm{O}$ and $\mathrm{SO}_{2}$ ). However the complexity of the preparation methods and high cost of the catalysts prevented their implementation. Preparation methods, conditions of testing and results of the activity tests of mixed manganese oxide catalysts are summarized in Table 1. 
TABLE 1. Methods of preparation and results of ACTIVITY tests of bulk mixed Mn containing catalysts

\begin{tabular}{|c|c|c|c|c|}
\hline Catalyst & $\begin{array}{c}\text { Preparation method } \\
\text { (T calcination) }\end{array}$ & Reaction conditions & $\begin{array}{c}\mathbf{X}_{\mathrm{NOx}} / \text { selectivity to } \mathbf{N}_{2} \text { (temperature } \\
\text { region) }\end{array}$ & References \\
\hline $\mathrm{MnO}_{\mathrm{x}}-\mathrm{CuO}$ & Co-precipitation $\left(350^{\circ} \mathrm{C}\right)$ & $0.05 \% \mathrm{NH}_{3}, 0.05 \% \mathrm{NO}_{2}, 5 \% \mathrm{O}_{2}, 30000 \mathrm{~h}^{-1}$ & $100 \%\left(50-200^{\circ} \mathrm{C}\right)$ & {$[19]$} \\
\hline $\mathrm{MnO}_{\mathrm{x}}-\mathrm{SnO}_{2}$ & Redox co-precipitation $\left(500^{\circ} \mathrm{C}\right)$ & $0.05 \% \mathrm{NH}_{3}, 0.05 \% \mathrm{NO}_{2}, 3 \% \mathrm{O}_{2}$ & $100 \%\left(120-200^{\circ} \mathrm{C}\right)$ & {$[22]$} \\
\hline $\begin{array}{c}\mathrm{MnO}_{\mathrm{x}}-\mathrm{FeO}_{\mathrm{x}}- \\
\mathrm{TiO}_{2}\end{array}$ & Co-precipitation $\left(400^{\circ} \mathrm{C}\right)$ & $0.05 \% \mathrm{NH}_{3}, 0.05 \% \mathrm{NO}, 5 \% \mathrm{O}_{2}, 50000 \mathrm{~h}^{-1}$ & $100 \% />90 \%\left(200-300^{\circ} \mathrm{C}\right)$ & {$[23]$} \\
\hline $\mathrm{MnO}_{\mathrm{x}}-\mathrm{CeO}_{2}$ & Co-precipitation $\left(650^{\circ} \mathrm{C}\right)$ & $0.1 \% \mathrm{NH}_{3}, 0.1 \% \mathrm{NO}, 2 \% \mathrm{O}_{2}, 42000 \mathrm{~h}^{-1}$ & $100 \%\left(120-150^{\circ} \mathrm{C}\right)$ & {$[20][24]$} \\
\hline $\mathrm{MnO}_{\mathrm{x}}-\mathrm{FeO}_{\mathrm{x}}$ & Co-precipitation $\left(500^{\circ} \mathrm{C}\right)$ & $\begin{array}{c}0.1 \% \mathrm{NH}_{3}, 0.1 \% \mathrm{NO}_{2} \% \mathrm{O}_{2}, \\
15000 \mathrm{~h}^{-1}\end{array}$ & $100 \%\left(120-180^{\circ} \mathrm{C}\right)$ & {$[25]$} \\
\hline
\end{tabular}

Calcination temperature has a substantial effect on the catalyst crystallinity and structure. For instance, an increase of the calcination temperature of $\mathrm{Fe}-\mathrm{Ti}$ catalyst leads to an increase of particle size and a decrease of specific surface area [26]. Addition of manganese to the catalyst based on iron titanate resulted in an increase of specific surface area and porosity, distortion of the crystal structure and a corresponding rise of the oxygen mobility [23]. However the effect of the surface area on the catalyst activity in the SCR reaction is debatable and the correlations between the activity and the specific surface area are sometimes not observed. Thus, in [25] mixed oxides of metals: Fe-Mn, Fe-Mn- $\mathrm{Zr}$ and Fe-Mn-Ti were prepared by a co-precipitation method and $\mathrm{S}_{\mathrm{BET}}$ values for these catalysts were $54,178,183 \mathrm{~m}^{2} / \mathrm{g}$, respectively. These mixed oxides showed high activity in the SCR reaction. At $80^{\circ} \mathrm{C}$ the NO conversion was $68-74 \%$ and reached $100 \%$ at $120^{\circ} \mathrm{C}$, while the specific surface area of the most active $\mathrm{Fe}$ Mn catalyst was considerably lower in comparison with other mixed oxides. The reaction products on these catalysts were $\mathrm{N}_{2}$ and $\mathrm{H}_{2} \mathrm{O}$, at the same time the selectivity to $\mathrm{N}_{2}$ on the simple oxide $\mathrm{MnO}_{\mathrm{x}}$ was only $8-35 \%$ at the same testing conditions. In the presence of water vapor the catalyst activity decreased insignificantly. The authors explain high activity of these catalysts by their ability to oxidize $\mathrm{NO}$ to $\mathrm{NO}_{2}$. In earlier publications these authors [27], [28] showed the rate of interaction of $\mathrm{NH}_{3}$ with $\mathrm{NO}_{2}$ considerably higher than that of $\mathrm{NH}_{3}$ with $\mathrm{NO}$ [27].

The most promising catalysts for SCR reaction are metal and metal oxide systems deposited on various supports. The role of the support is to provide high dispersion of the active component and sufficient pore space for the reaction. An important criterion for the support selection is its resistance to sulfur. Therefore much attention is paid to the elaboration of Mo and W based catalysts capable of suppressing the formation of sulfur trioxide from $\mathrm{SO}_{2}$. The majority of supported catalysts are synthesized by the impregnation method, because this method is rather simple and allows one to control the concentration of deposited active components.

\section{Supported vanadium-titanium catalysts}

Currently, most well-known commercial catalyst used in industrial SCR- $\mathrm{NH}_{3}$ processes is $\mathrm{V}_{2} \mathrm{O}_{5}$ promoted with $\mathrm{WO}_{3}$ or $\mathrm{MoO}_{3}$ and supported on $\mathrm{TiO}_{2}$. The temperature of the catalyst operation is in the range of $300-400^{\circ} \mathrm{C}$. However the temperature of flue gases of thermal power plants or other stationary nitrogen oxide sources can be lower, this is just the case when the SCR system is installed after the desulfurization system. So, much attention is paid to improve the catalyst activity of vanadium-titanium catalysts at lower temperatures (below $250^{\circ} \mathrm{C}$ ).

It is known that the activity of $\mathrm{V}_{2} \mathrm{O}_{5} / \mathrm{TiO}_{2}$ catalysts depends on many factors: vanadia structure (polymeric/monomeric/crystal), dispersion of vanadia particles, crystal form of $\mathrm{TiO}_{2}$, chemical nature of the second metal, electric conductivity. The efficiency of the process can be increased by synthesis of $\mathrm{V} / \mathrm{TiO}_{2}$ catalysts with nonstoichiometric valence state of vanadium oxides. It was shown that catalysts containing non-stoichiometric forms of vanadium $\left(\mathrm{V}^{4+}, \mathrm{V}^{3+}, \mathrm{V}^{2+}\right)$ and titanium $\left(\mathrm{Ti}^{3+}, \mathrm{Ti}^{2+}\right)$ had the Fermi level close to or above the conductivity band making possible electron transfer with low activation energy. It is established that the efficiency of deNOx has a linear dependence on the number of non-stoichiometric $\mathrm{V}$ and $\mathrm{Ti}$ forms per unit catalyst volume.

A significant aspect of the $\mathrm{SCR}$ reaction on $\mathrm{V} / \mathrm{TiO}_{2}$ catalysts is oxidation of $\mathrm{NO}$ to $\mathrm{NO}_{2}$. Koebel et al. showed that an increase of $\mathrm{NO}_{2} / \mathrm{NO}$ ratio to $50 \%$ enhanced $\mathrm{NO}_{\mathrm{x}}$ conversion to $95 \%$. It is known that superoxide ions can accelerate NO oxidation NO. In this connection the use of F-doping of $\mathrm{V} / \mathrm{TiO}_{2}$ catalyst promoting the formation of superoxide ions increases the catalyst activity in the SCR reaction. It was shown that F-doping improved the interaction of $\mathrm{V}$ with $\mathrm{TiO}_{2}$ with the help of electrons from oxygen vacancies shifting to $\mathrm{V}$ and taking part in the creation of reduced $\mathrm{V}$ species that acted as active sites in the formation of superoxide ions. Another paper of these authors describes the role of $\mathrm{WO}_{3}$ in the SCR activity of the $\mathrm{V}_{2} \mathrm{O}_{5}-\mathrm{WO}_{3} / \mathrm{TiO}_{2}$ catalyst. It is shown that $\mathrm{WO}_{3}$ interacts with $\mathrm{TiO}_{2}$, participates in $\mathrm{V}_{2} \mathrm{O}_{5}$ hybridization and improves electron transfer, thus providing the formation of reduced forms of vanadium oxide. These aspects affect the processes of $\mathrm{NO}$ oxidation and $\mathrm{NO}_{3}{ }^{-}$decomposition that determine the high activity of $\mathrm{V}_{2} \mathrm{O}_{5}-\mathrm{WO}_{3} / \mathrm{TiO}_{2}$ catalyst. Addition of $\mathrm{CeO}_{2}$ to $\mathrm{V}_{2} \mathrm{O}_{5}-\mathrm{WO}_{3} / \mathrm{TiO}_{2}$ catalyst increases the dispersion of oxides of $\mathrm{V}$ and $\mathrm{W}$, improves $\mathrm{NO}_{\mathrm{x}}$ adsorption and accelerates the SCR reaction due to synergistic effect of $\mathrm{Ce}, \mathrm{V}$ and $\mathrm{W}$ compounds. Cerium oxides have an excess of oxygen vacancies, which is an important factor in the redox cycle.

\section{Supported Mn-containing catalysts}

Manganese oxides supported on various carriers: $\mathrm{MnO}_{\mathrm{x}} / \mathrm{Al}_{2} \mathrm{O}_{3}, \mathrm{MnO}_{\mathrm{x}} / \mathrm{TiO}_{2}$ and $\mathrm{MnO}_{\mathrm{x}} / \mathrm{AC}$ are considered very efficient in the $\mathrm{NH}_{3}-\mathrm{SCR}$. Their high $\mathrm{NO}_{x}$ removal efficiency $(80-100 \%)$ is observed in a wide temperature range (195$\left.600^{\circ} \mathrm{C}\right)$. 
Manganese catalysts on $\mathrm{TiO}_{2}$ were shown to be very effective at low temperatures. The preparation methods and the activity of these catalysts are described well in literature. The catalysts can be synthesized by different methods; the most dispersed structures are formed when the sol-gel method is used. It was found that in the synthesis of $\mathrm{Mn} / \mathrm{TiO}_{2}$ catalysts, $\mathrm{MnO}_{2}$ was formed from the manganese nitrate precursor, and in case of manganese acetate as a precursor $\mathrm{Mn}_{2} \mathrm{O}_{3}$ was formed on the support surface. The activity of the catalyst prepared from $\mathrm{Mn}$ acetate was higher due to higher surface concentration of $\mathrm{Mn}_{2} \mathrm{O}_{3}$ particles.

Titania nanotubes have greater surface area and hollow foliated structure in comparison with powder titanium dioxide. The results of the study by a number of physicochemical methods showed that high-dispersed particles of manganese oxide prepared by the impregnation method are distributed on the walls of structured anatase nanotubes. The effects of the content of the active component, reaction conditions (space velocity, oxygen concentration, $\left[\mathrm{NH}_{3}\right] /[\mathrm{NO}]$ ratio and $\mathrm{NO}$ concentration) on the activity were studied. It is shown that at temperature $150^{\circ} \mathrm{C},\left[\mathrm{NH}_{3}\right] /[\mathrm{NO}]$ ratio equal to $1.2,\left[\mathrm{O}_{2}\right]=3 \%$, $[\mathrm{NO}]=0.06 \%$, space velocity $23613.8 \mathrm{~h}^{-1}$ and at the $\mathrm{Mn}$ content in the catalyst $5-15 \%$ the conversion of NO attains $95 \%$. The catalyst is deactivated in the presence of water at $180^{\circ} \mathrm{C}$, but it regains the activity when the water vapor is removed from the stream. At high temperatures the catalyst is resistant to the action of water. Sulfur dioxide also deactivates the catalyst, but in the presence of water the stability of the catalyst in the presence of $\mathrm{SO}_{2}$ is considerably higher. After the removal of water and $\mathrm{SO}_{2}$ from the stream the activity of the catalyst is recovered, but it does not attain the initial level.

Carbon materials, such as activated carbon (AC), activated carbon nanofibers (ACNF) and activated carbon nanotubes (ACNT) are used in $\mathrm{DeNO}_{\mathrm{x}}$ processes not only as sorbents but also as catalyst supports. The advantages of these amorphous materials are large pore volume and high specific surface area. The catalysts $\mathrm{Mn}-\mathrm{Ce} / \mathrm{Mn}-\mathrm{Fe}-\mathrm{Ce} / \mathrm{Mn}-\mathrm{V}-\mathrm{Ce}$ deposited onto composite carbon-ceramic monolithic supports $\mathrm{Ce}_{2} \mathrm{O}_{3} / \mathrm{ACNF}$ and $\mathrm{La}_{2} \mathrm{O}_{3} / \mathrm{SCNF}, \mathrm{V}_{2} \mathrm{O}_{5} / \mathrm{TiO}_{2}-\mathrm{CNT}$ were shown to be efficient in $\mathrm{NH}_{3}$-SCR.

\section{E. Supported catalysts of complex composition}

Supported copper oxides are good candidates for the $\mathrm{NH}_{3}$ SCR process as an alternative for widely used commercial VTi catalysts due to their good low temperature activity, low toxicity and low price. It is known that the behavior of copper containing catalysts is determined by the texture and dispersion of $\mathrm{CuO}$ structures, which, in their turn, depend on the chemical nature of the support. Introduction of additional components to the main metal oxide or support can significantly modify and improve catalyst performance due to mutual electron or structural interaction. Liu and co-authors studied a composite catalyst based on oxides of copper, titanium, cerium and concluded that the synergistic effect of coupled redox cycles $\left(\mathrm{Cu}^{2+}+\mathrm{Ce}^{3+} \leftrightarrow \mathrm{Cu}^{+}+\mathrm{Ce}^{4+}{ }_{\text {и }} \mathrm{Cu}^{2+}+\mathrm{Ti}^{3+} \leftrightarrow\right.$ $\left.\mathrm{Cu}^{+}+\mathrm{Ti}^{4+}\right)$ is a key factor determining high activity and selectivity of the catalysts in the $\mathrm{SCR}-\mathrm{NH}_{3}$ reaction, and also the resistance to the action of $\mathrm{SO}_{2}$ and $\mathrm{H}_{2} \mathrm{O}$. Introduction of
$\mathrm{Ce}^{4+}$ into the lattice of anatase $\mathrm{TiO}_{2}$ leads to the formation of unstable distorted octahedral $\mathrm{Cu}^{2+}$ structure in $\mathrm{CuO} / \mathrm{Ti}_{0,95} \mathrm{Ce}_{0,05} \mathrm{O}_{2}$ catalyst and an increase of electronic interaction between the active component and the support through the above-mentioned coupled redox cycles. This leads to the formation of a greater number of Lewis acid centers on the catalyst surface and activation of the reagents, resulting in an increase of the activity in the SCR.

The authors also established the dependence of the activity on the molar ratio $\mathrm{Ce} / \mathrm{Zr}$ in $\mathrm{Cu}-\mathrm{Ce}-\mathrm{Zr} / \mathrm{TiO}_{2}$ catalyst and found the most efficient catalyst composition $\mathrm{Cu}-\mathrm{Ce}_{0,25}-\mathrm{Zr}_{0,75} / \mathrm{TiO}_{2}$. The addition of $\mathrm{Zr}$ and/or Ce oxide improves the copper oxide dispersion, prevents copper oxide crystallization, promotes partial introduction of $\mathrm{Cu}$ ions into the lattice of ceria (zirconia), which results in the improvement of redox properties of $\mathrm{Cu}-\mathrm{Ce}-\mathrm{Zr} / \mathrm{TiO}_{2}$ catalyst and enhances the activity.

$\mathrm{WO}_{3}-\mathrm{CeO}_{2}-\mathrm{TiO}_{2}$ catalyst prepared by a sol-gel method demonstrated very good activity in the $\mathrm{NH}_{3}$-SCR reaction under conditions of low oxygen concentration. The mutual electronic and structural influence of oxides of $\mathrm{W}$ and $\mathrm{Ce}$ in the catalyst leads to an increase of a number of structural defects in the samples, weakening of Ce-O bond, a decrease of the crystallite size and can activate gas phase oxygen, compensating lattice oxygen consumed in the $\mathrm{NH}_{3}$-SCR reaction. Both types of acid centers - Brønsted sites on the surface of $\mathrm{W}$ oxides and Lewis sites on Ce oxides participate in the $\mathrm{NH}_{3}$ adsorption and stabilize the adsorbed $\mathrm{NH}_{3}$ species that can be favorable for the efficient deNOx reaction.

\section{F. Zeolite catalysts}

Many $\mathrm{Fe}, \mathrm{Cu}$ and $\mathrm{Mn}$ containing ion-exchanged zeolites are considered as promising NH3-SCR catalysts due to their high activity and selectivity. Metal exchanged zeolites, such as Cu-ZSM-5, Co-ZSM-5 and Fe-ZSM-5 were studied as catalysts for selective $\mathrm{NO}_{\mathrm{x}}$ reduction. Zeolite supports provide acid centers for $\mathrm{NH}_{3}$ adsorption, and transition metals play a key role in catalyzing $\mathrm{NO}$ oxidation and formation of adsorbed surface $\mathrm{NO}_{\mathrm{x}}$ complexes. $\mathrm{Cu}$ zeolites are more efficient in $\mathrm{NO}_{\mathrm{x}}$ reduction at low temperature in comparison with $\mathrm{Fe}$ analogues, which is connected with higher activity of copper in the process of $\mathrm{NO}$ oxidation. Although Fe zeolites have low activity in the low temperature SCR under steady state conditions, they exhibit even higher activity as compared to $\mathrm{Cu}$ zeolites, in unsteady state regimes .

The activity of zeolite catalysts depends on the zeolite type and the $\mathrm{Si} / \mathrm{Al}_{2}$ ratio. The structural acidity can be modified by variation of $\mathrm{Si} / \mathrm{Al}_{2}$, zeolite framework type and by partial replacement of $\mathrm{Al}$ by some other trivalent ion. For preparation of catalysts in ZSM-5, mordenite, beta, ferrierite, Y-zeolite with $\mathrm{Si} / \mathrm{Al}_{2}$ ratios $29,20,22,20,80$, respectively were used. The active cations $\mathrm{H}, \mathrm{Cu}, \mathrm{Fe}$ and $\mathrm{Ag}$ were introduced by ion exchange. Among the studied catalysts $\mathrm{Fe}$-beta, $\mathrm{Cu}$-ferrierite, $\mathrm{Cu}$-mordenite, Fe-ZSM-5 were most stable under hydrothermal conditions. These catalysts exhibited the highest activity in $\mathrm{NH}_{3}-\mathrm{SCR}$ in a wide temperature range. The authors concluded that hydrothermal conditions modify acid properties of catalysts. The more stable the zeolite acidity, the 
greater the hydrothermal stability in the SCR reaction. In copper-exchanged ultrastabilized zeolite $\mathrm{Y}$ was shown to exhibit high activity at low temperatures and offer high hydrothermal resistance in comparison with other metal containing ion-exchanged zeolites. The observed low temperature activity of the Cu-USY catalyst was linked to the high abundance of Lewis $\mathrm{Cu}^{+}$sites and their distribution which were detected by in situ FTIR analyses using CO adsorption.

\section{G. Monolithic catalysts}

Monolithic catalysts used in $\mathrm{NH}_{3}-\mathrm{SCR}$ process possess unique functional characteristics, such as high mechanical strength, low pressure drop, resistance to deposition of particulates (soot, ash, metals) formed in fuel combustion and maintainability.

Usually a homogeneous mixture of oxides of titanium, tungsten or molybdenum and vanadium molded into monoliths with honeycomb structure is used as the commercial catalyst for SCR of flue gases from thermal power plants . The SCR monoliths are assembled into standard modules and inserted into a reactor to form catalyst layers. Each catalyst layer contains individual retractable catalyst elements. This kind of modular construction allows flexibility of use.

In monolithic SCR catalysts were prepared by deposition of thin layer of $\mathrm{V}_{2} \mathrm{O}_{5}-\mathrm{WO}_{3}-\mathrm{TiO}_{2}$ slurry on monolithic supports prepared mainly from clay. The catalytic composition was similar to that in the commercial SCR catalyst, but the scientists used authorial approaches protected by Chinese patents on preparation methods. Such catalyst containing washcoat on $30 \times 30 \mathrm{~mm}$ square monoliths with 16 channels of rectangular form showed high activity in the presence of $5 \%$ $\mathrm{O}_{2}$ and $1000 \mathrm{ppm} \mathrm{SO}_{2}$. The catalyst activity increased with an increase of the washcoat thickness, and when it reached 110 $\mu \mathrm{m}$ the activity was similar to that of $100 \%$ active componentmolded honeycomb. This showed the reaction to proceed mainly in the surface layer of the washcoat deposited onto support. The catalyst was tested with gas mixtures obtained in coal combustion in a special reactor and containing NO 400 ppm, $\mathrm{SO}_{2} 100$ ppm, $\mathrm{CO} 300$ ppm, $\mathrm{O}_{2} 4 \%, \mathrm{CO}_{2}$ 15\%. It was shown that $\mathrm{NO}$ conversion increased with temperature from $58.8 \%$ at $280^{\circ} \mathrm{C}$ to $71.5 \%$ at $350^{\circ} \mathrm{C}$. These experiments prove that such catalysts in the form of washcoated layers can be successfully used in industry.

Preparation methods of monolithic catalysts containing active components V-Ti-O, Cu-Ti-O, Cu-ZSM-5, Co-ZSM-5 prepared as washcoat on the surface of monolithic ceramic and metal oxide supports. It was shown that under certain conditions of the active component formation the activity of the studied samples was comparable to the activity of bulk honeycomb catalysts prepared by extrusion. The active component $\mathrm{Cr}-\mathrm{V} / \mathrm{TiO}_{2}$ was deposited onto cordierite monolith by in-situ precipitation and impregnation without use of binders. The difference between traditional methods and the in-situ precipitation was the alkaline treatment of the coating. The $\mathrm{TiOSO}_{4}$ on the surface was alkalized to $\mathrm{TiO}(\mathrm{OH})_{2}$ by ammonia, and then decomposed to $\mathrm{TiO}_{2}$ by calcination. It was shown that the alkaline treatment increased loading of the $\mathrm{TiO}_{2}$ layer and improved its adhesion to the cordierite surface.

In monoliths made from $\mathrm{CeO}_{2}-\mathrm{ZrO}_{2}-\mathrm{Al}_{2} \mathrm{O}_{3}$ (CZA) were used as catalyst supports. It was shown that monolithic catalysts $\mathrm{MnO}_{\mathrm{x}} / \mathrm{CZA}$ were more active than $\mathrm{MnO}_{\mathrm{x}} / \mathrm{TiO}_{2}$. An increase of $\mathrm{Mn}$ content up to $10 \mathrm{wt} \%$ in the catalyst resulted in an increase of the activity. Manganese oxides in the composition of the most active catalyst are highly dispersed and amorphous. The catalysts are stable under joint presence of water vapor and $\mathrm{SO}_{2}$.

A series of monolithic acidic zirconium-based composite oxide catalysts were prepared by different methods. The catalyst $10 \% \mathrm{CeO}_{2} / \mathrm{ZrTiSiWO}_{\mathrm{x}}$ prepared by impregnation presented good $\mathrm{NH}_{3}$-SCR activity and high $\mathrm{N}_{2}$ selectivity in a broad operation temperature window, comparatively strong tolerance of gas hourly space velocities (GHSV), water, sulfur and hydrothermal aging. Compared with $\mathrm{V}_{2} \mathrm{O}_{5} / \mathrm{TiSiWO}_{\mathrm{x}}$ and Fe-ZSM-5 catalysts, the $\mathrm{CeO}_{2} / \mathrm{ZrTiSiWO}_{x}$ catalyst showed a better $\mathrm{NH}_{3}-\mathrm{SCR}$ performance; more than $80 \% \mathrm{NO}_{\mathrm{x}}$ could be removed in the temperature range of $277-545^{\circ} \mathrm{C}$ under GHSV of $30,000 \mathrm{~h}^{-1}$. It was suggested that the main reason for the high $\mathrm{NH}_{3}-\mathrm{SCR}$ activity of the $\mathrm{CeO}_{2} / \mathrm{ZrTiSiWO}$ catalyst was high surface atomic concentration of $\mathrm{Ce}$ active centers.

\section{CONCLUSION}

Currently, the most efficient catalytic process for $\mathrm{NO}_{\mathrm{x}}$ removal from flue gases of thermal power plants is selective catalytic reduction of $\mathrm{NO}_{\mathrm{x}}$ with ammonia using $\mathrm{V}_{2} \mathrm{O}_{5^{-}}$ $\mathrm{WO}_{3}\left(\mathrm{MoO}_{3}\right)-\mathrm{TiO}_{2}$ catalysts. For the solution of the problem of the SCR catalyst deactivation from the action of $\mathrm{SO}_{2}$, particulates and ash the catalyst modules are often placed downstream desulfurization system and electrostatic precipitator. In this case the gas temperature is substantially decreased. Therefore, the main direction of contemporary SCR research is development of new deNOx catalytic systems efficient at temperatures below $200^{\circ} \mathrm{C}$. In this connection, attention is paid to the chemical nature of the catalyst supports, development of modified composite systems with high redox potential and high concentration of Lewis and Brønsted acid centers and formation of surface nonstoichiometric states of active components. Catalysts in the form of honeycomb monoliths are considered most promising for $\mathrm{NH}_{3}$-SCR process, however for their successful practical application development of new preparation methods is required, directed to solution of economical issues and improvement of the catalyst physicochemical properties, such as chemical composition, textural and structural, distribution of the active component, an increase of the oxygen capacity, mechanical strength and thermal stability.

\section{ACKNOWLEDGMENT}

The work was performed with financial support of the state in the name of the Ministry of Education and Science of the Russian Federation within implementation of the Federal target program 'Researches and Development on the Priority Directions of Development of the Scientific and Technological Complex of Russia for 2014-2020', as per the Agreement №14.583.21.0004 on the subsidy granting of July 16, 2014. 
The unique identifier of scientific researches (project) is RFMEFI58314X0004.

\section{REFERENCES}

[1] Z.R. Ismagilov, M.A. Kerzhentsev. Environmentally clean fuel combustion and catalytic purification of flue gases of thermal power plants from nitrogen oxides: state-of-the-art and prospects. Zh. Vses. Khim. Ova (Journal of the All-Union Mendeleev Chemical Society), 199035 (1) 43-54 (in Russian).

[2] R.I.Kuzmina, V.P.Sevostianov. Catalytic purification of off-gases from nitrogen oxides and carbon monoxide. Ross. Khim. Zh. (Russian Chemical Journal), 200044 (1) 71-75 (in Russian).

[3] Z.R. Ismagilov, M.A. Kerzhentsev. Catalytic fuel combustion-a way of reducing emission of nitrogen oxides. Catalysis Reviews - Science and Engineering, 199032 (1-2) 51-103.

[4] Y. Zhao, Y. Han, T. Ma, T. Guo. Simultaneous desulfurization and deNOx from flue gas by Ferrate (VI). Environment Science and Technology, 201145 (9) 4060-4065.

[5] Y. Zhao, X. Sun, P. Xu, S. Ma, L. Wang, F. Liu. Mechanism of flue gas simultaneous desulfurization and deNOx using the highly reactive absorbent. Science in China Series E Technological Sciences, 200548 (6) $692-705$.

[6] R. Lyon. Method for the Reduction of the Concentration of NO in Combustion Effluents Using Ammonia. Pat. USA, No. 3, 900, 554 (1975).

[7] M.A. Gomez-Garcia, V. Pitchon, A. Kiennemann. Pollution by NITROGEN OXIDES: AN APPROACH TO NOX ABATEMENT BY USING SORBING CATALYTIC MATERIALS. ENVIRONMENT INTERNATIONAL, 2005 31 445-467.

[8] K. Skalska, J. S. Miller, S. Ledakowicz. Trends in NOx abatement: A review. Science of the Total Environment, 2010408 3976-3989.

[9] Z.R Ismagilov, M.A. Kerzhentsev, T.L. Susharina. Catalytic METHODS FOR LOWERING THE AMOUNT OF NITROGEN OXIDES IN EXHAUST GASES ON COMBUSTION OF FUEL., 199059 (10) 973-988.

[10] G. Marbán, T.VAldÉs-Solís, A.B. Fuertes. MechanisM of LOWTEMPERATURE SELECTIVE CATALYTIC REDUCTION OF NO WITH $\mathrm{NH}_{3}$ OVER CARBON-SUPPORTED $\mathrm{MN}_{3} \mathrm{O}_{4}$ : ROLE OF SURFACE $\mathrm{NH}_{3}$ SPECIES: SCR MECHANISM. JOURNAL OF CATALYSIS, 2004226138 155.

[11] W.S. Kijlstra, D.S. Brands, E.K. Poels, A. Bliek. Mechanism of THE SELECTIVE CATALYTIC REDUCTION OF NO BY $\mathrm{NH}_{3}$ OVER $\mathrm{MNOX} / \mathrm{AL}_{2} \mathrm{O}_{3}$. JOURNAL OF CATALYSIS, 1997171 208-218.

[12] F. EIGENMANN, M. MACIEJEWSKI, A. BAIKER. SElECTIVE REDUCTION OF NO BY $\mathrm{NH}_{3}$ OVER MANGANESE-CERIUM MIXED OXIDES: RELATION BETWEEN ADSORPTION, REDOX AND CATALYTIC BEHAVIOR. APPLIED CATALYSIS B: ENVIRONMENTAL, 200662 311-318.

[13] J. Eng, C.H. Bartholomew. Kinetic and Mechanistic Study of NOXREDUCTION BY $\mathrm{NH}_{3}$ OVER H-FORM ZEOLITES. JOURNAL OF CATALYSIS, 1997171 27-44.

[14] R.Q. LONG, R.T. Yang. Reaction Mechanism of SElective CATALYTIC REDUCTION OF NO WITH $\mathrm{NH}_{3}$ OVER FE-ZSM-5 CATALYST. JOURNAL OF CATALYSIS, 2002207 224-231.

[15] K. Li, X. Tang, H. Yi, P. Ning, D. Kang, C. Wang. Low-temperature catalytic oxidation of NO over Mn-Co-Ce-Ox catalyst. Chemical Engineering Journal, 2012192 99-104.
[16] F. Kapteijn, L. Singoredjo, A. Andreini, J.A. Moulijn. Activity and selectivity of pure manganese oxides in the selective catalytic reduction of nitric oxide with ammonia. Applied Catalysts B: Environmental, 1994 3 173-189.

[17] X. Tang, J. Li, L. Sun, J. Hao. Origination of $\mathrm{N}_{2} \mathrm{O}$ from $\mathrm{NO}$ reduction by $\mathrm{NH}_{3}$ over $\beta-\mathrm{MnO}_{2}$ and $\alpha-\mathrm{Mn}_{2} \mathrm{O}_{3}$. Applied Catalysts B: Environmental, 201099 156-162.

[18] M. Kang, E.D. Park, J.M. Kim, J.E. Yie. Manganese oxide catalysts for $\mathrm{NO}_{x}$ reduction with $\mathrm{NH}_{3}$ at low temperatures. Applied Catalysis A: General, 2007327 261-269.

[19] M. Kang, E.D. Park, J.M. Kim, J.E. Yie. Cu-Mn mixed oxides for low temperature $\mathrm{NO}$ reduction with $\mathrm{NH}_{3}$. Catalysis Today, 2006111 236-241.

[20] G. Qi, R. Yang. Performance and kinetics study for low-temperature SCR of $\mathrm{NO}$ with $\mathrm{NH}_{3}$ over $\mathrm{MnO}_{\mathrm{x}}-\mathrm{CeO}_{2}$ catalyst. Journal of Catalysis, 2003 217 434-441.

[21] M. Casapu, O. Krocher, M. Elsener. Screening of doped $\mathrm{MnO}_{\mathbf{x}}-\mathrm{CeO}_{2}$ catalysts for low-temperature NO-SCR. Applied Catalysis B: Environmental, 200988 413-419.

[22] X. Tang, J. Li, L. Wei, J. Hao. $\mathrm{MnO}_{\mathrm{x}}-\mathrm{SnO}_{2}$ Catalysts Synthesized by a Redox Coprecipitation Method for Selective Catalytic Reduction of NO by $\mathrm{NH}_{3}$. Chinese Journal of Catalysis, 200829 531-536.

[23] F.D. Liu, H. He. Selective catalytic reduction of $\mathrm{NO}$ with $\mathrm{NH}_{3}$ over manganese substituted iron titanate catalyst: Reaction mechanism and $\mathrm{H}_{2} \mathrm{O} / \mathrm{SO}_{2}$ inhibition mechanism study. Catalysis Today, 2010 153 70-76.

[24] G. Qi, R.T. Yang, R. Chang. $\mathrm{MnO}_{x}-\mathrm{CeO}_{2}$ mixed oxides prepared by coprecipitation for selective catalytic reduction of $\mathrm{NO}$ with $\mathrm{NH}_{3}$ at low temperatures. Applied Catalysis B: Environmental, 2004 51 93-106.

[25] R. Q. Long, R. T. Yang, R. Chang. Low temperature selective catalytic reduction (SCR) of $\mathrm{NO}$ with $\mathrm{NH}_{3}$ over $\mathrm{Fe}-\mathrm{Mn}$ based catalysts. Chemical Communications, 2002, 452-453.

[26] F. Liu, H. He, C. Zhang. Novel iron titanate catalyst for the selective catalytic reduction of $\mathrm{NO}$ with $\mathrm{NH}_{3}$ in the medium temperature range. Chemical Communications, 2008 2043-2045.

[27] R.Q. LONG, R.T. YANG. FTIR AND KINETIC STUDIES OF THE MECHANISM OF $\mathrm{FE}^{3+}$-EXChanged $\mathrm{TiO}_{2}$-PIllared Clay CATAlyst For SElEctive CATAlytic REDUCTION OF NO WITH AMMONIA. JOURNAL OF CATALYSIS, 2000190 22-31.

[28] R.Q. LONG, R.T. YANG. TEMPERATURE-PROGRAMMED DESORPTION/SURFACE REACTION (TPD/TPSR) STUDY OF FEEXCHANGED ZSM-5 FOR SELECTIVE CATALYTIC REDUCTION OF NiTRIC OXIDE BY AMMONIA. JOURNAL OF CATALYSIS, 2001198 20-28. 